\title{
Furfurylation Effects on Discoloration and Physical-Mechanical Properties of Wood from Tropical Plantation Forests
}

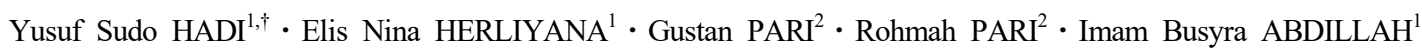

\begin{abstract}
Wood from tropical plantation forests has lower physical and mechanical properties than mature wood. Furfuryl alcohol (FA) impregnation into the wood could help to enhance hydrophobic properties, dimensional stability, and structural strength. Furfurylation was applied to specimens of the following four fast-growing tropical wood species: jabon (Anthocephalus cadamba), sengon (Falcataria moluccana), mangium (Acacia mangium), and pine (Pinus merkusii). The discoloration and physical and mechanical properties were subsequently measured, and the results showed that furfurylated wood had a darker color and better physical and mechanical properties than untreated wood. Specifically, the furfurylated wood had higher density, modulus of elasticity, and hardness and lower moisture content, water absorption, swelling, and shrinkage. The furfurylation significantly enhanced physical and mechanical properties.
\end{abstract}

Keywords: discoloration, furfuryl alcohol impregnation, polymerization, tropical wood, weight percent gain

\section{INTRODUCTION}

The demand of wood from sustainable resources increases every year, and fulfillment of consumer needs is currently dominated by wood from plantation forests. Log production in Indonesia increased by $5 \%$ each year in the period of 2015 to 2019 , with the log supply for wood industry reaching 56.6 million $\mathrm{m}^{3}$ and the value of exported forestry products reaching US\$ 11.6 billion in 2019 (MoEF, 2020). Compared with mature wood, wood from forest plantations of fast-growing wood species has lower physical and mechanical properties and also lower resistance to termite attack (Hadi et al., 2013, 2015, 2020). The primary advantage of fast-growing tree species is that the forest stand can be harvested in a short rotation, typically less than 10 years in tropical areas. In the future, wood from plantation forests could be used for building materials, but it needs improvement to attain high-quality performance.

Several types of chemical modifications and heat treatment of wood have been developed, such as acetylation (Hadi et al., 1995); impregnation with polystyrene (Hadi et al., 1998, 2016), methyl methacrylate (Cahyono et al., 2020; Hadi et al., 2018, 2019), 1,3-dimethylol-

Date Received June 28, 2021, Date Revised September 27, 2021, Date Accepted January 10, 2022

${ }^{1}$ IPB University (Bogor Agricultural University), Bogor 16680, Indonesia

${ }^{2}$ Center for Standardization of Sustainable Forest Management Instruments, Bogor 16118, Indonesia

† Corresponding author: Yusuf Sudo HADI (e-mail: yshadi@indo.net.id, https://orcid.org/0000-0002-2212-4501).

(C) Copyright 2022 The Korean Society of Wood Science \& Technology. This is an Open-Access article distributed under the terms of the Creative Commons Attribution Non-Commercial License (http://creativecommons.org/licenses/by-nc/4.0/) which permits unrestricted non-commercial use, distribution, and reproduction in any medium, provided the original work is properly cited. 
4,5-dihydroxy-ethylene-urea (Militz, 1993), poisonous organic materials (Arsyad et al., 2019), monoethylene glycol (MEG) (Dirna et al., 2020), and thermosetting resin (Park and Park, 2021; Sandberg et al., 2017; Sumardi et al., 2020); heat treatment (Esteves and Pereira, 2009); thermo-mechanical treatment (Yunianti et al., 2019), and furfurylation (Lande et al., 2004). These modifications enhance the physical-mechanical properties as well as durability of the wood, and they enable avoiding the use of toxic products. The use of furfuryl alcohol (FA) in the chemical modification of the wood requires other chemicals (e.g., a catalyst), as well as a polymerization process at several or elevated temperatures (Dong et al., 2014).

According to Dong et al. (2014), furfurylation leads to the filling of voids in the wood, with the polymer becoming chemically bound to cell walls after polymerization. This treatment has the potential to enhance wood quality. In particular, furfurylation involves a bio-based polymer that could improve the chemical and flame resistance of wood as well as its structural strength (Karami et al., 2018). Dong et al. (2015) and Jia and Fiedler (2018) reported that furfurylation enhanced the mechanical properties, dimensional stability, and hydrophobic properties of wood. Buchelt et al. (2012) found that FA treatment affected the plasticization and compression capability of wood, and a previous study by Szymona et al. (2014) reported that the durability of low-density biomass increased 4 to 8 times in association with a medium to high weight percent gain (WPG) based on the furfurylation level. Lande et al. (2008) reported that furfurylation has been used in the manufacture of wood products such as furniture, construction materials, and flooring.

The FA impregnation process can affect the chemical bonds and degree of crystallinity within wood due to chemical reactions during the vacuum-pressure and polymerization processes. These changes can in turn alter the wood color and other aspects of its appearance, which are determined by the chemical compounds in its structure, including cellulose, hemicelluloses, lignin, and extractives (Aydemir et al., 2012). Color is one of the surface characteristics of the wood, and a discoloration is an indication of alteration in the chemical composition (Hrčková et al., 2018). For example, in a previous study, Hadi et al. (2005) showed that higher WPG due to furfurylation was associated with a darker wood color.

Polymerization of FA is induced by using various catalysts, such as citric acid (Lande et al., 2004), maleic anhydride (Dong et al., 2014), and tartaric acid (Sejati et al., 2017). The utilization of tartaric acid as a catalyst for furfurylation of tropical wood species is still limited and needs to be developed. This study aimed to analyze the physical-mechanical properties of furfurylated wood from four fast-growing tropical wood species and to determine which type of wood experienced the greatest improvements.

\section{MATERIALS and METHODS}

\subsection{Materials}

Furfuryl alcohol $(\geq 98 \%)$ and tartaric acid (pure grade, $\geq 99.5 \%$ ) were purchased from PT Merck Tbk (Jakarta, Indonesia). Wood from four fast-growing tropical tree species, namely jabon, sengon, mangium, and pine, was collected from forest stands in the Bogor area, Indonesia. A flat sawn pattern was used to cut the logs into timber, and wood specimens were manufactured from the timber. The dimension of wood specimen was $5 \mathrm{~cm}$ by $5 \mathrm{~cm}$ by $5 \mathrm{~cm}$ (width, length, and thickness) for physical properties test; $30 \mathrm{~cm}$ in longitudinal direction with $2 \mathrm{~cm}$ by $2 \mathrm{~cm}$ in cross section for mechanical properties (including modulus of elasticity [MOE] and modulus of rupture [MOR]); and $6 \mathrm{~cm}$ in longitudinal with $2 \mathrm{~cm}$ by $2 \mathrm{~cm}$ in cross section for hardness test. After the furfurylation process, the specimens were used 
to determine the physical-mechanical properties of the wood. Untreated specimens were used as controls for comparison purposes.

The test specimen sizes for physical properties of wood, including density, moisture content (MC), water absorption, swelling, and shrinkage, were tested based on ASTM D 2395-07 (ASTM, 2007). British Standard 373:1957 (BS, 1957) was used as the reference for testing the mechanical properties of wood, including MOE, MOR, and hardness.

\subsection{Furfurylation}

Logs of jabon (Anthocephalus cadamba), sengon (Falcataria moluccana), mangium (Acacia mangium), and pine (Pinus merkusii) with a diameter less than 20 $\mathrm{cm}$ were harvested from a plantation forest that was less than ten years old in Bogor, Indonesia. Jabon, sengon and mangium were broadleaf, and pine was conifer which originally from Sumatra island in Indonesia. The four woods are well-known and popularly processed for wood industries.

Impregnation of FA into the wood could involve two processes. First, FA molecules interact with each other and these aggregated molecules fill the void space in the wood. Second, FA chemically reacts with wood components especially lignin (Gérardin, 2016; Hadi et al., 2021). Tartaric acid was added to the FA solution at a ratio of 5:100 by weight. The air-dried wood samples were placed under vacuum at $600 \mathrm{~mm} \mathrm{Hg}$ for $30 \mathrm{~min}$, which was followed by immersion in FA and pressure at $10 \mathrm{~kg} / \mathrm{cm}^{2}$ for $30 \mathrm{~min}$. The vacuum-pressure method used was based on Hadi et al. (2015). After FA impregnation, the specimens were wrapped in aluminum foil and heated at $100^{\circ} \mathrm{C}$ for 24 hours. Afterward, the aluminum foil was opened, and the wood specimens were left under ambient conditions for 4 weeks. The weights of wood specimen before and after furfurylation process were measured to get WPG values. Ten replicate speci- mens were prepared for each wood species and treatment.

\subsection{Discoloration determination}

The CIELab method was used to determine wood color. This method involved directly measuring the values of $\mathrm{L}^{*}, \mathrm{a}^{*}$, and $\mathrm{b}^{*}$ from a photograph (which was obtained from scanning with CanonScan 4400F [Canon, Tokyo, Japan]) of the wood sample, using the ImageJ program. $L^{*}$ indicated lightness, with a value of 0 to 100 (black to white); $\mathrm{a}^{*}$ indicated colors from green to red, with $+\mathrm{a}^{*}$ from 0 to 80 corresponding to red and $-\mathrm{a}^{*}$ from -80 to 0 corresponding to green; and $\mathrm{b}^{*}$ indicated colors from blue to yellow, with $+b^{*}$ from 0 to 70 corresponding to yellow and $-\mathrm{b}^{*}$ from -70 to 0 corresponding to blue (Christie, 2001). Each sample was assessed at five points, and the average values were used in the analysis. The color change $(\triangle \mathrm{E})$ was calculated according to the CIELab method (Hunter Lab, 1996), using Equation (1):

$$
\Delta \mathrm{E}=\sqrt{\left(\Delta \mathrm{L}^{*}\right)^{2}+\left(\Delta \mathrm{a}^{*}\right)^{2}+\left(\Delta \mathrm{b}^{*}\right)^{2}}
$$

Where

$\triangle \mathrm{E}=$ color change

$\triangle L^{*}=$ difference in $L^{*}$ values between compared samples $\triangle \mathrm{a}^{*}=$ difference in $\mathrm{a}^{*}$ values between compared samples $\Delta \mathrm{b}^{*}=$ difference in $\mathrm{b}^{*}$ values between compared samples

According to Hunter Lab (1996) and Hrčková et al. (2018), color change can be classified as shown in Table 1.

\subsection{Physical and mechanical properties testing}

The procedures for testing physical and mechanical properties were based on Hadi et al. (2019) as follows: 
Table 1. Color change classification

\begin{tabular}{ccl}
\hline Class & Color difference & \multicolumn{1}{c}{ Color change effect } \\
\hline \hline 1 & $\Delta \mathrm{E}<0.2$ & Invisible changes \\
2 & $0.2<\Delta \mathrm{E}<2.0$ & Very small changes \\
3 & $2.0<\Delta \mathrm{E}<3.0$ & Small changes (color changes visible by high-quality filter) \\
4 & $3.0<\Delta \mathrm{E}<6.0$ & Medium changes (color changes visible by medium-quality filter) \\
5 & $6.0<\Delta \mathrm{E}<12$ & Large changes (distinct color changes) \\
6 & $\Delta \mathrm{E}>12$ & Different color \\
\hline
\end{tabular}

WPG was determined by weighing the oven-dry wood specimen before treatment $\left(\mathrm{W}_{1}\right)$ and after impregnation with FA $\left(\mathrm{W}_{2}\right)$. The WPG was calculated using Equation (2):

$\mathrm{WPG}(\%)=\left(\mathrm{W}_{2}-\mathrm{W}_{1}\right) / \mathrm{W}_{1} \times 100$

MC was determined with oven-dry weight method. Each air-dry specimen was weighed to obtain its initial weight $\left(\mathrm{W}_{3}\right)$, and then it was placed in an oven at 103 $\pm 2^{\circ} \mathrm{C}$ until reaching a constant weight, the oven-dry weight $\left(\mathrm{W}_{1}\right)$. The $\mathrm{MC}$ was calculated with Equation (3):

$\operatorname{MC}(\%)=\left(\mathrm{W}_{3}-\mathrm{W}_{1}\right) / \mathrm{W}_{1} \times 100$

Wood density was determined by measuring the volume of each wood specimen in the air-dry condition $\left(\mathrm{V}_{1}\right)$ and its oven-dry weight $\left(\mathrm{W}_{1}\right)$ and then calculating the density using Equation (4):

Density $\left(\mathrm{g} / \mathrm{cm}^{3}\right)=\mathrm{W}_{1} / \mathrm{V}_{1}$

Water absorption was determined by immersing the wood specimens in water at room temperature for 48 hours. Afterward, the weight $\left(\mathrm{W}_{4}\right)$ and volume $\left(\mathrm{V}_{2}\right)$ of each specimen was determined. Water absorption was determined calculating the amount of water absorbed $\left(\mathrm{W}_{4}-\mathrm{W}_{1}\right)$ and comparing the result with the initial oven-dry weight $\left(\mathrm{W}_{1}\right)$, according to Equation (5):

Water absorption $(\%)=\left(\mathrm{W}_{4}-\mathrm{W}_{1}\right) / \mathrm{W}_{1} \times 100$

Swelling was determined by comparing the change in volume (the difference between the initial oven-dry condition $\left(\mathrm{V}_{3}\right)$ and the condition after immersion in water $\left.\left(\mathrm{V}_{2}\right)\right)$, using Equation (6):

$$
\text { Swelling }(\%)=\left(V_{2}-V_{3}\right) / V_{3} \times 100
$$

For calculating shrinkage, specimens that had been immersed in water were placed in the oven until reaching oven-dry condition again. The subsequent ovendry volumes were then determined $\left(\mathrm{V}_{4}\right)$, and the volume shrinkage was calculated as shown in Equation (7):

Shrinkage $(\%)=\left(\mathrm{V}_{4}-\mathrm{V}_{2}\right) / \mathrm{V}_{2} \times 100$

Anti-swell efficiency (ASwE) was determined by finding the difference between swelling of the untreated wood $\left(\mathrm{sw}_{1}\right)$ and that of furfurylated wood $\left(\mathrm{sw}_{2}\right)$ and comparing it to $\mathrm{sw}_{1}$. Anti-shrink efficiency (AShE) was based on a comparison between the difference between the shrinkage of untreated wood $\left(\mathrm{sh}_{1}\right)$ and that of furfurylated wood $\left(\mathrm{sh}_{2}\right)$ and comparing it to $\mathrm{sh}_{1}$. The two characteristics were calculated as shown in Equa- 
tions (8) and (9):

$\operatorname{ASwE}(\%)=\left(\mathrm{sw}_{1}-\mathrm{sw}_{2}\right) / \mathrm{sw}_{1} \times 100$

$\operatorname{AShE}(\%)=\left(\mathrm{sh}_{1}-\mathrm{sh}_{2}\right) / \mathrm{sh}_{1} \times 100$

MOE and MOR were obtained by conducting bending tests with an Instron Universal Testing Machine (type 3369). Testing was done by placing a single-point load on the span of a sample, with $28 \mathrm{~cm}$ between the points of support of the test piece. Loading orientation was perpendicular to the tangential face of the test specimen, and a loading speed of $3.5 \mathrm{~mm} / \mathrm{min}$ was used. The MOE and MOR were calculated using Equations (10) and (11):

$$
\begin{aligned}
& \operatorname{MOE}\left(\mathrm{kgf} / \mathrm{cm}^{2}\right)=\left(\triangle \mathrm{P} \mathrm{L}^{3}\right) /\left(4 \triangle \mathrm{Y} \mathrm{b} \mathrm{h}^{3}\right) \\
& \operatorname{MOR}\left(\mathrm{kgf} / \mathrm{cm}^{2}\right)=(3 \mathrm{P} \mathrm{L}) /\left(2 \mathrm{~b} \mathrm{~h} \mathrm{~h}^{2}\right)
\end{aligned}
$$

where $\triangle P$ is the difference between the upper and lower loading limits in the proportional limit region (kgf); $\triangle \mathrm{Y}$ is the deflection (cm); $\mathrm{P}$ is maximum loading (kgf); L is span $(\mathrm{cm}) ; \mathrm{b}$ is the width of the test specimen $(\mathrm{cm})$; and $\mathrm{h}$ is the thickness of the specimen (cm).

Hardness was determined through the Janka test, which was done using a hemispherical steel ball with a diameter of $1.128 \pm 0.005 \mathrm{~cm}$ in order to determine the required load until a depth of $0.564 \mathrm{~cm}$ was achieved on the surface of the test specimen. The loading orientation was perpendicular to the tangential face of the test specimen.

\subsection{Data analysis}

The effect of treatments on all properties was analyzed using a completely randomized block design, in which the block was wood species and wood furfurylation was the treatment. The data were analyzed with IBM SPSS version 22. Duncan's multiple range tests were performed for further analysis if the block factor was significantly different $(p \leq 0.05)$.

\section{RESULTS and DISCUSSION}

\subsection{Wood discoloration}

Fig. 1 shows the colors of the wood specimen. The color characteristics $\left(\mathrm{L}^{*}, \mathrm{a}^{*}\right.$, and $\left.\mathrm{b}^{*}\right)$ and discoloration $(\triangle E)$ of the wood specimens are shown in Table 2, and a summary of the analysis of variance (ANOVA) results is presented in Table 3.

From Table 2, it could be seen that the values of lightness $\left(\mathrm{L}^{*}\right)$ of untreated wood were higher than furfuryl wood for all wood species, which indicated that the furfuryl wood had darker color than untreated wood. The values of $a^{*}$ and $b^{*}$ were also changed but the changes were not as big as the $\mathrm{L}^{*}$ value.

According to the analysis presented in Table 3, the $L^{*}$ value was affected by wood species and furfurylation. As shown in Fig. 1, the untreated wood had a light color, with mangium being naturally darker than the other three wood species. The difference is reflected in the $\mathrm{L}^{*}$ value of mangium (50.8) being much lower

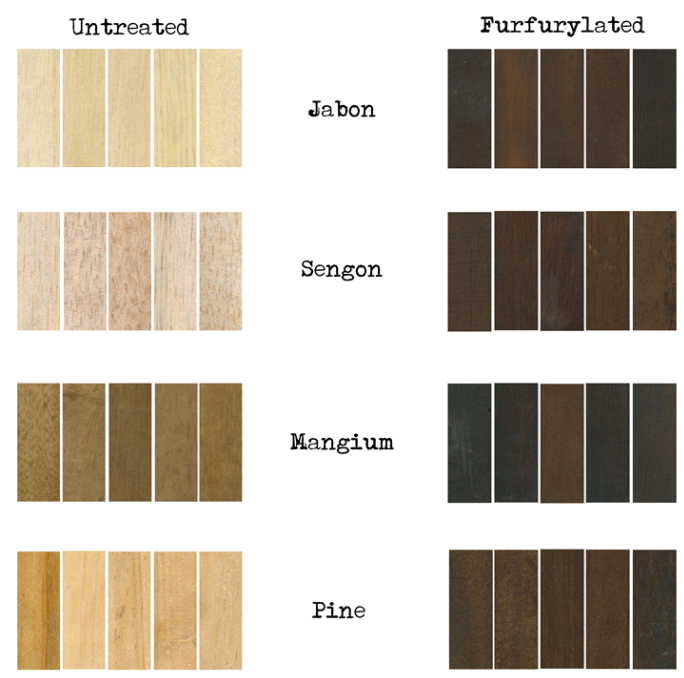

Fig. 1. Color of untreated and furfurylated woods. 
Table 2. Wood color characteristic $\left(\mathrm{L}^{*}, \mathrm{a}^{*}\right.$, and $\left.\mathrm{b}^{*}\right)$ and discoloration of wood

\begin{tabular}{|c|c|c|c|c|c|}
\hline Wood sp. & Treatment & $\mathrm{L}^{*}$ & $a^{*}$ & $\mathrm{~b}^{*}$ & $\triangle \mathrm{E}$ \\
\hline \multirow{2}{*}{ Jabon } & Untreated & $82.4(1.5)^{\mathrm{d}}$ & $1.6(0.6)^{\mathrm{a}}$ & $24.2(2.4)^{\mathrm{c}}$ & \multirow{2}{*}{$58.1(3.6)^{\mathrm{c}}$} \\
\hline & Furfurylated & $26.2(3.3)^{\mathrm{a}}$ & $3.6(1.8)^{\mathrm{abc}}$ & $10.4(4.5)^{\mathrm{a}}$ & \\
\hline \multirow{2}{*}{ Sengon } & Untreated & $81.2(0.8)^{\mathrm{cd}}$ & $5.8(0.8)^{\mathrm{cd}}$ & $18.2(1.9)^{\mathrm{b}}$ & \multirow{2}{*}{$56.1(2.1)^{\mathrm{bc}}$} \\
\hline & Furfurylated & $25.8(2.1)^{\mathrm{a}}$ & $4.2(1.6)^{\mathrm{bc}}$ & $11.0(3.1)^{\mathrm{a}}$ & \\
\hline \multirow{2}{*}{ Mangium } & Untreated & $50.8(3.9)^{\mathrm{b}}$ & $5.6(0.9)^{\mathrm{cd}}$ & $26.4(2.9)^{\mathrm{c}}$ & \multirow{2}{*}{$32.9(5.9)^{\mathrm{a}}$} \\
\hline & Furfurylated & $24.2(4.0)^{\mathrm{a}}$ & $2.4(2.2)^{\mathrm{ab}}$ & $7.6(3.5)^{\mathrm{a}}$ & \\
\hline \multirow{2}{*}{ Pine } & Untreated & $77.4(3.8)^{\mathrm{c}}$ & $7.0(1.0)^{\mathrm{d}}$ & $33.2(2.6)^{\mathrm{d}}$ & \multirow{2}{*}{$52.9(3.7)^{b}$} \\
\hline & Furfurylated & $27.8(4.4)^{\mathrm{a}}$ & $5.6(3.3)^{\mathrm{cd}}$ & $15.6(3.4)^{\mathrm{b}}$ & \\
\hline
\end{tabular}

Values in parentheses are standard deviations.

a-d Values followed by the same letter within a columns are not statistically different based on Duncan's multiple range test.

Table 3. Summary of ANOVA results ( $F$ test) for discoloration

\begin{tabular}{lcc}
\hline \multicolumn{1}{c}{ Response } & Wood sp (A) & FA treatment $(\mathrm{B})$ \\
\hline \hline $\mathrm{L}^{*}$ value & $* *$ & $* *$ \\
$\mathrm{a} *$ value & $* *$ & $* *$ \\
$\mathrm{~b} *$ value & $* *$ & $* *$ \\
Discoloration $(\triangle \mathrm{E})$ & $* *$ & $* *$ \\
\hline
\end{tabular}

** Highly significant difference $(p<0.01)$.

ANOVA: analysis of variance, FA: furfuryl alcohol.

than the other three wood species (77.4-82.4, with an average of 80.3). After the FA treatment, the lightness of the wood specimens was similar, with all of them becoming much darker. This change was indicated by the average $\mathrm{L}^{*}$ values for untreated wood being 73.0 and those for furfurylated wood being 26.0 (range: 24.227.8); these values were significantly different from one another. However, furfurylated wood specimens, which all had a higher intensity of black color, were not significantly different from each other.

For the other colors, average $\mathrm{a}^{*}$ values (green to red color) were 5.0 for untreated wood and 4.0 for furfurylated wood. The change in $\mathrm{a}^{*}$ ranged from -2.0 to 3.2 points, indicating that furfurylated wood did not differ much from untreated wood. In the case of mangium, the $a^{*}$ value change was the highest at 3.2 points (5.6 to 2.4) and the color shifting toward green. For the $b^{*}$ value (blue to yellow), untreated wood was 25.2 and furfurylated wood 11.2 points; this change of 14.1 points was higher than that for $\mathrm{a}^{*}$ but lower than that for $\mathrm{L}^{*}$. In summary, furfurylation caused the wood to become more blue (14.1 point reduction) and much more black (26.0 point reduction), but the color of green to red ( $a^{*}$ value) changed very little (1.0 point reduction).

The color of all furfurylated wood specimens differed from that of control wood specimens, as indicated by all $\triangle \mathrm{E}$ values being more than 12 points. Mangium had the smallest $\triangle \mathrm{E}$ because the untreated wood of this species was already darker than that of the other species, but after furfurylation all wood had a similar dark color. Hadi et al. (2005) showed that the intensity of discoloration is affected by the WPG level of FA, with a higher WPG resulting in a greater discoloration toward a darker color. In other words, a lower discoloration value, especially the lightness, could be arranged with a lower level of WPG from FA treatment. This possibility was also suggested by Dong et al. (2016), who found that furfurylation could cause discoloration in all wood specimens, especially decreasing the $L^{*}$ value (i.e., 
becoming darker). In addition, the reported that the intensity of the discoloration depended on the polymer loading value.

\subsection{Physical properties}

Physical properties of the control and FA wood specimens, such as WPG, density, MC, water absorption, swelling, and shrinkage, are described for all four wood species and furfurylated wood in Table 4.

WPG indicated FA polymer loading into the wood. From Table 4, it could be mentioned that jabon had the lowest density and thus much more void space available for occupation by the polymer; consequently, it had the highest WPG. Although the density of sengon was only slightly higher than that of jabon, its WPG was much less because sengon wood has a waving or interlocking grain, and the fresh cut timber had a smell of Parkia sp fruit (Martawijaya et al., 1989). In addition, they informed that fiber length, fiber diameter, and lumen diameter were $1,979 \mu \mathrm{m}, 54 \mu \mathrm{m}$, and $48 \mu \mathrm{m}$ for jabon, and $1,242 \mu \mathrm{m}, 46 \mu \mathrm{m}$, and $39 \mu \mathrm{m}$ for sengon, respectively; number of pore, ray height, and ray width were 2$5 / \mathrm{mm}^{2}, 580 \mu \mathrm{m}$, and $44 \mu \mathrm{m}$ for jabon, and $1-3 / \mathrm{mm}^{2}$, $185 \mu \mathrm{m}$, and $16 \mu \mathrm{m}$ for sengon, respectively. From these characteristics, it seems that jabon had more void for FA to enter than sengon.

Furthermore, sengon has the highest extractive content, with a soluble extraction rate of $19.6 \%$ in $\mathrm{NaOH} 1 \%$ compared with jabon (18.4\%), pine (11.1\%) (Martawijaya et al., 1989), and mangium (16.3\%) (Siagian et al., 1999). In addition, Pari (1998) reported that sengon contained extractive substances, such as cellobiose, glucose, xylose, arabinose, ribose, oligosaccharide, penta-saccha-

Table 4. Physical properties of treated specimens of each wood species

\begin{tabular}{|c|c|c|c|c|c|}
\hline Property & Treatment & Jabon & Sengon & Mangium & Pine \\
\hline WPG (\%) & FA wood & $86.3(6.0)^{\mathrm{a}}$ & $30.1(3.7)^{b}$ & $19.1(4.8)^{\mathrm{c}}$ & $15.2(4.9)^{\mathrm{c}}$ \\
\hline \multirow{2}{*}{ Density $\left(\mathrm{g} / \mathrm{cm}^{3}\right)$} & Untreated & $0.34(0.02)^{\mathrm{a}}$ & $0.36(0.05)^{\mathrm{a}}$ & $0.60(0.05)^{\mathrm{c}}$ & $0.72(0.04)^{d}$ \\
\hline & FA wood & $0.64(0.02)^{\mathrm{c}}$ & $0.46(0.05)^{\mathrm{b}}$ & $0.73(0.09)^{\mathrm{d}}$ & $0.83(0.05)^{\mathrm{e}}$ \\
\hline \multirow{2}{*}{$\begin{array}{c}\text { Moisture } \\
\text { content }(\%)\end{array}$} & Untreated & $12.61(0.63)^{\mathrm{e}}$ & $11.46(1.12)^{\mathrm{d}}$ & $11.03(1.23)^{\mathrm{e}}$ & $9.69(1.26)^{\mathrm{d}}$ \\
\hline & FA wood & $2.11(0.34)^{\mathrm{a}}$ & $2.65(0.36)^{\mathrm{ab}}$ & $3.75(0.44)^{\mathrm{c}}$ & $3.16(0.34)^{\mathrm{bc}}$ \\
\hline \multirow{2}{*}{$\begin{array}{c}\text { Water } \\
\text { absorption }(\%)\end{array}$} & Untreated & $66.9(6.6)^{\mathrm{f}}$ & $41.2(4.9)^{\mathrm{e}}$ & $32.3(4.0)^{\mathrm{d}}$ & $27.5(3.6)^{\mathrm{c}}$ \\
\hline & FA wood & $5.85(0.64)^{\mathrm{a}}$ & $6.57(0.63)^{\mathrm{a}}$ & $7.63(0.69)^{\mathrm{ab}}$ & $10.65(1.02)^{b}$ \\
\hline \multirow{2}{*}{ Swelling (\%) } & Untreated & $8.01(0.97)^{\mathrm{d}}$ & $8.01(0.68)^{\mathrm{d}}$ & $11.08(1.02)^{\mathrm{f}}$ & $9.75(0.74)^{\mathrm{e}}$ \\
\hline & FA wood & $1.38(0.20)^{\mathrm{a}}$ & $2.38(0.19)^{\mathrm{b}}$ & $2.63(0.32)^{\mathrm{b}}$ & $4.21(0.51)^{\mathrm{c}}$ \\
\hline $\begin{array}{l}\text { Anti-swelling } \\
\text { efficiency (\%) }\end{array}$ & FA wood & 82.7 (2.7) & $70.0(4.4)$ & $76.2(2.1)$ & $56.7(5.3)$ \\
\hline \multirow{2}{*}{ Shrinkage $(\%)$} & Untreated & $6.89(0.42)^{\mathrm{e}}$ & $3.18(0.36)^{\mathrm{c}}$ & $4.15(0.59)^{\mathrm{d}}$ & $10.40(1.16)^{\mathrm{f}}$ \\
\hline & FA wood & $1.40(0.27)^{\mathrm{a}}$ & $1.39(0.23)^{\mathrm{a}}$ & $1.96(0.20)^{\mathrm{b}}$ & $3.69(0.60)^{\mathrm{d}}$ \\
\hline $\begin{array}{l}\text { Anti-shrinkage } \\
\text { efficiency }(\%)\end{array}$ & FA wood & $79.6(4.1)$ & $55.9(8.7)$ & $52.0(6.6)$ & $63.9(8.3)$ \\
\hline
\end{tabular}

Values in parentheses are standard deviations.

${ }^{a-f}$ Values followed by the same letter within a row are not statistically different based on Duncan's multiple range test. WPG: weight percent gain, FA: furfuryl alcohol. 
ride, long-chain fatty-acids such as capriate acid, myristic acid, myristoleic acid, pentadecylic acid, palmitic acid, margaric acid, stearic acid, oleic acid, linoleic acid, and arachidonic acid. The extractive content of sengon likely hindered the FA monomer from entering the void space of the wood. Mangium and pine had much lower WPG values because these wood species have a much higher density than the other two wood species. Their thicker cell walls and less void space meant that less FA could penetrate into the wood.

According to the ANOVA results presented in Table 5 , wood species had a significant effect on polymer loading. Jabon wood had the highest WPG, which was significantly different from that of sengon. Mangium and pine were not different from each other, but both differed from the other two species. WPG of pine only reached $15 \%$, which was lower than the WPG reported by Esteves et al. (2011). They treated sapwood of Pinus pinaster with a $70 \%$ FA mixture and obtained a WPG of $38 \%$. Wood species and catalyst could explain the WPG difference. Rahman et al. (2017) suggested that a 50:50 ratio of FA to 2-ethylhexyl methacrylate was the most suitable for impregnation of FA into wood.

At air-dry condition, the densities of untreated jabon

Table 5. ANOVA results ( $F$ test) for physical properties

\begin{tabular}{lcc}
\hline \multicolumn{1}{c}{ Property } & Wood species & FA treatment \\
\hline \hline Polymer loading $(\%)$ & $* *$ & $* *$ \\
Density $\left(\mathrm{g} / \mathrm{cm}^{3}\right)$ & $* *$ & $* *$ \\
Moisture content $(\%)$ & $* *$ & $* *$ \\
Water absorption $(\%)$ & $* *$ & $* *$ \\
Swelling (\%) & $* *$ & $* *$ \\
Anti-swelling efficiency & $* *$ & $* *$ \\
Shrinkage $(\%)$ & $* *$ & $* *$ \\
Anti-shrinkage efficiency & $* *$ & $* *$ \\
\hline
\end{tabular}

** Highly significant difference $(p<0.01)$.

ANOVA: analysis of variance, FA: furfuryl alcohol. and sengon were low $\left(0.34\right.$ and $0.36 \mathrm{~g} / \mathrm{cm}^{3}$, respectively), while those of untreated mangium and pine were medium ( 0.60 and $0.72 \mathrm{~g} / \mathrm{cm}^{3}$, respectively). The density of wood specimens affected their physical and mechanical properties. The furfurylated wood specimens had a higher density than the untreated specimens, and the increment of the density of the specimens was proportional to the WPG value. As shown by the ANOVA results in Table 5, wood species and FA treatment affected wood density. Further statistical analysis showed that the density of furfurylated wood was significantly higher than that of untreated wood for all species.

The ANOVA results in Table 5 also show that the MC of wood was affected by treatment and wood species. The MC of furfurylated wood was $74 \%$ lower than that of untreated wood, and this decrease was much greater than the results reported by Esteves et al. (2011). They found that the average WPG of $P$. pinaster was $38 \%$ and the equilibrium MC decreased by more than $40 \%$. The presence of FA polymers in the wood could reduce its MC because they occupy the void space in the wood; in addition, FA polymers could bind to cell wall molecules (Gérardin, 2016).

With regard to wood species and MC of untreated wood, higher-density wood specimens tended to have a lower MC. This was likely because the wood had thicker cell walls, which prevented water from reaching the inner parts. In contrast, wood with a lower density has thinner cell walls, which would allow water to more easily enter all parts of the cell wall. In the case of furfurylated wood, the opposite occurred. Higher-density wood that was furfurylated tended to have a higher MC because the inner cell wall components did not easily bind with FA. The higher density meant that the FA monomer had difficulty reaching the inner cell wall components. However, in the lower-density wood, the FA monomer could easily reach more cell wall components. Consequently, the cell wall became more hydrophobic due to FA filling the void space and binding to 
cell wall components (Gérardin, 2016).

Based on the ANOVA results in Table 5, treatment and wood species affected water absorption of the wood. The average water absorption of untreated wood was $42.0 \%$ and that of furfurylated wood was only $7.7 \%$, representing an $82 \%$ decrease compared with untreated wood. This finding was similar to that of Morozovs et al. (2018), who reported that wood furfurylation decreased water absorption by $80 \%$ compared with untreated wood.

Furfurylated wood had FA polymer in the void space, resulting in less space for free water. It also had fewer available hydroxyl groups in the cell wall components, which meant less water could be held via hydrogen bonds by the cell wall. Both factors could result in water absorption of furfurylated wood being much less than that of untreated wood. Regarding wood species, untreated wood with a higher density tended to have a lower water absorption value probably because the void space was much smaller and the cell wall was much thicker than wood with lower density. Consequently, the wood with a higher density would have had less free water able to occupy the void. Further analysis with Duncan's multiple range test (Table 4) showed that samples of all four untreated wood species had significantly different water absorption values, with the lowest-density wood (jabon) waving the highest average water absorption value and the highest-density wood (pine) having the lowest.

Based on the ANOVA results in Table 5, FA treatment and wood species significantly affected wood swelling and shrinkage. Swelling and shrinkage values of furfurylated wood were much lower than those of untreated wood, which was indicated by the anti-swell efficiency reaching a range of $56.7 \%$ to $82.7 \%$ (average: $69 \%$ ) and AShE reaching $52.0 \%$ to $79.6 \%$ (average: $62 \%$ ). The FA treatment improved the dimensional stability of the wood, and this finding was in line with Li et al. (2015), who reported that furfurylation signifi- cantly improved the dimensional stability and durability of pine wood. Morozovs et al. (2018) found that wood furfurylation decreased swelling by $40 \%$ during cyclic hydrothermal treatment compared with untreated wood. Furfurylated wood would have less swelling and shrinkage because the void space is filled with FA polymer. Further, hydroxyl groups in the cell wall would react with FA, yielding a more hydrophobic cell wall.

\subsection{Mechanical properties}

Mechanical properties, such as MOE, MOR, strength class, side hardness, and end hardness of untreated and furfurylated wood specimens, are described in Table 6 for the four wood species. Results of the ANOVA for each property are described in Table 7.

According to the results in Table 7, MOE was significantly affected by wood species and FA treatment factors. Jabon and sengon had lower MOE because they had lower density compared to the other. Pine had the highest MOE regarding to having highest density, and this matter was in-line with Epmeier et al. (2004) and Mardikanto et al. (2011).

In terms of FA treatment, the average $\mathrm{MOE}$ increment reached $14 \%$, and the results are similar to those of Jia and Fiedler (2018). They reported that FA pretreatment is a promising method for improving the mechanical properties of flax fiber composites (e.g. Young's modulus increases up to $18 \%$ ). Further analysis with Duncan's multiple range test showed that FA treatment did not significantly affect the MOE of jabon and pine wood, but it did increase the MOE of sengon and mangium specimens. The MOE improvement in sengon and mangium was in line with findings from Dong et al. (2015), who used fast-growing poplar (Populus sp.) in their research. The MOE increments of furfurylated wood compared with untreated wood differed for each species, and it appeared that wood density affected the parabolic to MOE increment. 
Table 6. Mechanical properties of wood specimens

\begin{tabular}{cccccc}
\hline Property & Treatment & Jabon & Sengon & Mangium & Pine \\
\hline \hline \multirow{2}{*}{$\begin{array}{c}\text { MOE } \\
\left(1,000 \mathrm{kgf} / \mathrm{cm}^{2}\right)\end{array}$} & Untreated & $52.7(4.4)^{\mathrm{a}}$ & $54.2(7.1)^{\mathrm{a}}$ & $73.7(5.5)^{\mathrm{c}}$ & $106.4(12.0)^{\mathrm{d}}$ \\
& FA wood & $54.1(3.9)^{\mathrm{a}}$ & $65.0(6.3)^{\mathrm{b}}$ & $101.6(8.1)^{\mathrm{d}}$ & $106.6(8.3)^{\mathrm{d}}$ \\
& Average & 53.4 & 59.6 & 87.7 & 106.5 \\
\hline \multirow{3}{*}{ MOR $\left(\mathrm{kgf} / \mathrm{cm}^{2}\right)$} & Untreated & $495(26)^{\mathrm{b}}$ & $455(39)^{\mathrm{b}}$ & $665(63)^{\mathrm{c}}$ & $979(105)^{\mathrm{e}}$ \\
& FA wood & $316(34)^{\mathrm{a}}$ & $459(43)^{\mathrm{b}}$ & $1,052(81)^{\mathrm{f}}$ & $847(55)^{\mathrm{d}}$ \\
& Average & 405.5 & 457.0 & 858.5 & 913.0 \\
\hline \multirow{2}{*}{ Strength class } & Untreated & IV & IV & III & II \\
\hline \multirow{2}{*}{$\begin{array}{l}\text { Hardness } \\
\left(\mathrm{kgf} / \mathrm{cm}^{2}\right)\end{array}$} & FA wood & IV & IV & II & II \\
\hline & FA wood & $262(36)^{\mathrm{c}}$ & $188(17)^{\mathrm{b}}$ & $478(35)^{\mathrm{e}}$ & $447(40)^{\mathrm{d}}$ \\
\hline
\end{tabular}

Values in parentheses are standard deviations.

a-f Values followed by the same letter within a row are not statistically different based on Duncan's multiple range test. MOE: modulus of elasticity, FA: furfuryl alcohol, MOR: modulus of rupture.

Table 7. ANOVA results ( $F$-test) for mechanical properties

\begin{tabular}{ccc}
\hline Response & Wood species (A) FA Treatment (B) \\
\hline \hline MOE $\left(1,000 \mathrm{kgf} / \mathrm{cm}^{2}\right)$ & $* *$ & $* *$ \\
MOR $\left(\mathrm{kgf} / \mathrm{cm}^{2}\right)$ & $* *$ & $\mathrm{~ns}$ \\
Hardness $\left(\mathrm{kgf} / \mathrm{cm}^{2}\right)$ & $* *$ & $* *$ \\
\hline
\end{tabular}

** Highly significant difference $(p<0.01)$; ns, nonsignificant difference.

ANOVA: analysis of variance, FA: furfuryl alcohol, MOE: modulus of elasticity, MOR: modulus of rupture.

The MOR was affected by wood species, but it was not affected by the FA treatment. Jabon and sengon had lower MOR because they had lower density compared to mangium and pine. Pine had the highest MOR regarding to having highest density among them, and this matter was in-line with Mardikanto et al. (2011).

Regarding to FA treatment, the MOR values of untreated sengon and FA sengon did not differ, but those for the other species did. For jabon and pine, the value decreased, but it increased for mangium. Using poplar wood, Dong et al. (2015) also showed that the MOR of furfurylated wood decreased compared with untreated wood. With regard to the strength class, furfurylated mangium only increased one class compared with untreated wood. Even though the MOR values decreased for the other wood species, the strength class did not decrease or was in the same class as untreated wood.

Wood hardness was significantly affected by wood species and FA treatment factors. Jabon and sengon had lower hardness because they had lower density compared to mangium and pine. Pine had the highest hardness regarding to having highest density among them, and this matter was in-line with Epmeier et al. (2004) and Mardikanto et al. (2011). In terms of FA treatment, the hardness of furfurylated wood increased by $44 \%$, and this result was similar to that of Esteves et al. (2011), who found that the hardness of furfurylated wood increased by about $50 \%$. With regard to the further data analysis of Duncan's multiple range test, the hardness of 
furfurylated jabon, sengon, and mangium specimens was higher than that of the untreated specimens; however, the values were not different for pine. In general, furfurylation of wood increased its hardness, and this result was in line with Dong et al. (2015), who reported that furfurylated poplar wood had improved hardness.

\section{CONCLUSION}

The wood densities of untreated jabon, sengon, mangium, and pine were lower than furfurylated wood and the WPG of the specimens after the impregnation process reached $86.3 \%, 30.1 \%, 19.1 \%$, and $15.2 \%$, respectively. The four furfurylated tropical wood species had different and darker colors that were more blue and black. On average, they had 74\% decreased MC, $82 \%$ decreased water absorption, and much higher dimensional stability, as indicated by an anti-swell efficiency of $69 \%$ and an AShE of $62 \%$ compared with untreated wood. The mechanical properties of furfurylated wood were enhanced in MOE (increased 14\%) and hardness (increased $44 \%$ ).

\section{CONFLICT of INTEREST}

No potential conflict of interest relevant to this article was reported.

\section{ACKNOWLEDGMENT}

This research was a part of Priority Basic Research of the University Grant (Penelitian Dasar Unggulan Perguruan Tinggi) Granted by the Ministry of Research and Technology - Research and Innovation Agency of the Indonesian Republic.

\section{REFERENCES}

American Society for Testing Materials [ASTM]. 2007.
Specific Gravity of Wood and Wood-based Materials (ASTM D2395-07). ASTM International, West Conshohocken, PA, USA.

Arsyad, W.O.M., Basri, E., Hendra, D., Trisatya, D.R. 2019. Termite resistance of impregnated jabon wood (Anthocephalus cadamba Miq.) with combined impregnant agents. Journal of the Korean Wood Science and Technology 47(4): 451-458.

Aydemir, D., Gunduz, G., Ozden, S. 2012. The influence of thermal treatment on color response of wood materials. Color Research and Application 37(2): 148153.

British Standard [BS]. 1957. Methods of Testing Small Clear Specimens of Timber. British Standards Institution, London, UK.

Buchelt, B., Dietrich, T., Wagenführ, A. 2012. Macroscopic and microscopic monitoring of swelling of beech wood after impregnation with furfuryl alcohol. European Journal of Wood and Wood Products 70(6): 865-869.

Cahyono, T.D., Darmawan, W., Priadi, T., Iswanto, A.H. 2020. Flexural properties of heat-treatment samama (Anthocephalus macrophyllus) wood impregnated by boron and methyl metacrylate. Journal of the Korean Wood Science and Technology 48(1): 76-85.

Christie, R.M. 2001. Colour Chemistry. Royal Society of Chemistry, London, UK.

Dirna, F.C., Rahayu, I., Zaini, L.H., Darmawan, W., Prihatini, E. 2020. Improvement of fast-growing wood species characteristics by MEG and nano $\mathrm{SiO}_{2}$ impregnation. Journal of the Korean Wood Science and Technology 48(1): 41-49.

Dong, Y., Qin, Y., Wang, K., Yan, Y., Zhang, S., Li, J., Zhang, S. 2016. Assessment of the performance of furfurylated wood and acetylated wood: Comparison among four fast-growing wood species. BioResources 11(2): 3679-3690.

Dong, Y., Yan, Y., Zhang, S., Li, J. 2014. Wood/polymer nanocomposites prepared by impregnation with fur- 
furyl alcohol and nano- $\mathrm{SiO}_{2}$. BioResources 9(4): 6028-6040.

Dong, Y., Yan, Y., Zhang, S., Li, J., Wang, J. 2015. Flammability and physical-mechanical properties assessment of wood treated with furfuryl alcohol and nano-SiO ${ }_{2}$. European Journal of Wood and Wood Products 73(4): 457-464.

Epmeier, H., Westin, M., Rapp, A. 2004. Differently modified wood: Comparison of some selected properties. Scandinavian Journal of Forest Research 19(sup 5): 31-37.

Esteves, B., Nunes, L., Pereira, H. 2011. Properties of furfurylated wood (Pinus pinaster). European Journal of Wood and Wood Products 69(4): 521-525.

Esteves, B.M., Pereira, H.M. 2009. Wood modification by heat treatment: A review. BioResources 4(1): 370-404.

Gérardin, P. 2016. New alternatives for wood preservation based on thermal and chemical modification of wood: A review. Annals of Forest Science 73(3): 559-570.

Hadi, Y.S., Darma, I.G.K.T., Febrianto, F., Herliyana, E.N. 1995. Acetylated rubberwood flakeboard resistance to bio-deterioration. Forest Products Journal 45(10): 64.

Hadi, Y.S., Massijaya, M.Y., Abdillah, I.B., Pari, G., Arsyad, W.O.M. 2020. Color change and resistance to subterranean termite attack of mangium (Acacia mangium) and sengon (Falcataria moluccana) smoked wood. Journal of the Korean Wood Science and Technology 48(1): 1-11.

Hadi, Y.S., Massijaya, M.Y., Arinana, A. 2016. Subterranean termite resistance of polystyrene-treated wood from three tropical wood species. Insects 7(3): 37.

Hadi, Y.S., Massijaya, M.Y., Hermawan, D., Arinana, A. 2015. Feeding rate of termites in wood treated with borax, acetylation, polystyrene, and smoke. Journal of the Indian Academy of Wood Science 12(1): 74-80.
Hadi, Y.S., Massijaya, M.Y., Zaini, L.H., Abdillah, I.B., Arsyad, W.O.M. 2018. Resistance of methyl methacrylate-impregnated wood to subterranean termite attack. Journal of the Korean Wood Science and Technology 46(6): 748-755.

Hadi, Y.S., Massijaya, M.Y., Zaini, L.H., Pari, R. 2019. Physical and mechanical properties of methyl methacrylate-impregnated wood from three fastgrowing tropical tree species. Journal of the Korean Wood Science and Technology 47(3): 324-335.

Hadi, Y.S., Mulyosari, D., Herliyana, E.N., Pari, G., Arsyad, W.O.M., Abdillah, I.B., Gérardin, P. 2021. Furfurylation of wood from fast-growing tropical species to enhance their resistance to subterranean termite. European Journal of Wood and Wood Products 79(4): 1007-1015.

Hadi, Y.S., Nawawi, D.S., Herliyana, E.N., Lawniczak, M. 1998. Termite attack resistance of four polystyrene-impregnated woods from Poland. Forest Products Journal 48(9): 60-62.

Hadi, Y.S., Rahayu, I.S., Danu, S. 2013. Physical and mechanical properties of methyl methacrylate impregnated jabon wood. Journal of the Indian Academy of Wood Science 10(2): 77-80.

Hadi, Y.S., Westin, M., Rasyid, E. 2005. Resistance of furfurylated wood to termite attack. Forest Products Journal 55(11): 85-88.

Hrčková, M., Koleda, P., Koleda, P., Barcík, Š., Štefková, J. 2018. Color change of selected wood species affected by thermal treatment and sanding. BioResources 13(4): 8956-8975.

Hunter Lab. 1996. Application note: Hunter color scale. Insight on Color 8(9): 1-4.

Jia, Y., Fiedler, B. 2018. Influence of furfuryl alcohol fiber pre-treatment on the moisture absorption and mechanical properties of flax fiber composites. Fibers 6:59.

Karami, Z., Zohuriaan-Mehr, M.J., Rostami, A. 2018. Biobased Diels-Alder engineered network from 
furfuryl alcohol and epoxy resin: Preparation and mechano-physical characteristics. ChemistrySelect 3(1): 40-46.

Lande, S., Eikenes, M., Westin, M., Schneider, M.H. 2008. Furfurylation of Wood: Chemistry, Properties, and Commercialization. In: Development of Commercial Wood Preservatives, American Chemical Society Symposium Series, Ed. by Schultz, T.P., Militz, H., Freeman, M.H., Goodell, B. and Nicholas, D.D. ACS Publications, Washington, DC, USA.

Lande, S., Westin, M., Schneider, M. 2004. Properties of furfurylated wood. Scandinavian Journal of Forest Research 19(sup 5): 22-30.

Li, W., Wang, H., Ren, D., Yu, Y., Yu, Y. 2015. Wood modification with furfuryl alcohol catalysed by a new composite acidic catalyst. Wood Science and Technology 49(4): 845-856.

Mardikanto, T.R., Karlinasari, L., Bahtiar, E.T. 2011. Sifat Mekanis Kayu. IPB Press, Bogor, Indonesia.

Martawijaya, A., Kartasujana, I., Mandang, Y.I., Prawira, S.A., Kadir, K. 1989. Atlas Kayu Indonesia, Jilid II. Pusat Penelitian dan Pengembangan Hasil Hutan, Bogor, Indonesia.

Militz, H. 1993. Treatment of timber with water soluble dimethylol resins to improve their dimensional stability and durability. Wood Science and Technology 27(5):347-355.

Ministry of Environment and Forestry [MoEF]. 2020. Statistik Lingkungan Hidup dan Kehutanan Tahun 2019 (Statistics of Environment and Forestry 2019). Ministry of Environment and Forestry, Jakarta, Indonesia.

Morozovs, A., Keke, A., Fisere, L., Spulle, U. 2018. Wood modification with furfuryl alcohol and furfurylated wood durability in water. In: Jelgava, Latvia, 17th International Scientific Conference Engineering for Rural Development, pp. 1445-1451. Pari, G. 1998. Zat Ekstraktif Kayu Sengon (Extractive of Sengon Wood). Perum Perhutani, Jakarta, Indonesia.

Park, S., Park, B.D., 2021. Crystallinity of low molar ratio urea-formaldehyde resins modified with cellulose nanomaterials. Journal of the Korean Wood Science and Technology 49(2): 169-180.

Rahman, M.R., Hamdan, S., Lai, J.C.H., Jawaid, M., Yusof, F.A.M. 2017. Physico-mechanical, thermal and morphological properties of furfuryl alcohol/2ethylhexyl methacrylate/halloysite nanoclay wood polymer nanocomposites (WPNCs). Heliyon 3(7): e00342.

Sandberg, D., Kutnar, A., Mantanis, G. 2017. Wood modification technologies: A review. iForest 10(6): 895-908.

Sejati, P.S., Imbert, A., Gérardin-Charbonnier, C., Dumarçay, S., Fredon, E., Masson, E., Nandika, D., Priadi, T., Gérardin, P. 2017. Tartaric acid catalyzed furfurylation of beech wood. Wood Science and Technology 51(2): 379-394.

Siagian, R.M., Darmawan, S., Saepuloh, S. 1999. Chemical composition of Acacia mangium Wild at several ages harvested from first rotation growth. Buletin Penelitian Hasil Hutan 17(1): 57-66.

Sumardi, I., Darwis, A., Saad, S., Rofii, M.N. 2020. Quality enhancement of falcataria-wood through impregnation. Journal of the Korean Wood Science and Technology 48(5): 722-731.

Szymona, K., Borysiuk, P., H'ng, P.S., Chin, K.L., Mamiński, M. 2014. Valorization of waste oil palm (Elaeis guineensis Jacq.) biomass through furfurylation. Materials \& Design 53: 425-429.

Yunianti, A.D., Kidung, T.P., Suhasman, S., Taskirawati, I., Agussalim, A., Muin, M. 2019. Modified densification process for increasing strength properties of pine and gmelina wood from community forests. Journal of the Korean Wood Science and Technology 47(4): 418-424. 